\title{
Total Selenium and Selenium Species in Irrigation Drain Inflows to the Salton Sea, California, October 2008 and January 2009
}

Open-File Report 2009-1123 



\section{Total Selenium and Selenium Species in Irrigation Drain Inflows to the Salton Sea, California, October 2008 and January 2009}

By Thomas W. May, Michael J. Walther, Michael K. Saiki, and William G. Brumbaugh

Open-File Report 2009-1123 


\title{
U.S. Department of the Interior \\ KEN SALAZAR, Secretary
}

\author{
U.S. Geological Survey \\ Suzette M. Kimball, Acting Director
}

U.S. Geological Survey, Reston, Virginia: 2009

For more information on the USGS - the Federal source for science about the Earth, its natural and living resources, natural hazards, and the environment, visit http://www.usgs.gov or call 1-888-ASK-USGS

For an overview of USGS information products, including maps, imagery, and publications, visit http://www.usgs.gov/pubprod

To order this and other USGS information products, visit http://store.usgs.gov

Any use of trade, product, or firm names is for descriptive purposes only and does not imply endorsement by the U.S. Government.

Although this report is in the public domain, permission must be secured from the individual copyright owners to reproduce any copyrighted materials contained within this report.

Suggested citation:

May, T.W., Walther, M.J., Saiki, M.K., and Brumbaugh, W.G., 2009, Total selenium and selenium species in irrigation drain inflows to the Salton Sea, California, October 2008 and January 2009: U.S. Geological Survey Open-File Report 2009-1123, 14 p. 


\section{Contents}

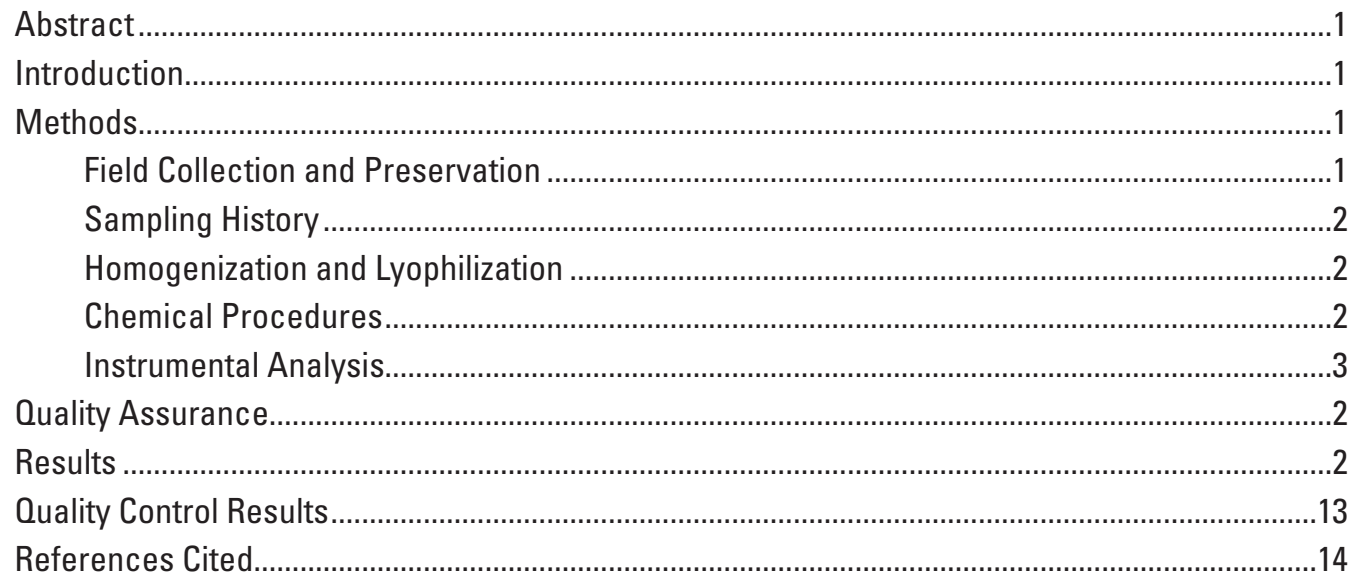

\section{Tables}

1. Total selenium concentrations in duplicates of unfiltered irrigation drain water samples, Salton Sea, California, October 2008

2. Total selenium concentrations in duplicates of unfiltered irrigation drain water samples, Salton Sea, California, January 2009.

3. Total dissolved selenium, dissolved selenium species, and particulate selenium concentrations in filtered irrigation drain water samples, Salton Sea, California, October 2008

4. Total suspended solids concentrations in unfiltered Salton Sea, California, irrigation drain water samples, October 2008 and January 2009.

5. Selenium concentrations in biota samples collected from Salton Sea, California, irrigation drains, October 2008

6. Selenium concentrations in detritus and sediment samples collected from Salton Sea, California, irrigation drains, October 2008

7. Particle size distributions in sediment samples collected from Salton Sea, California, irrigation drains, October 2008

8. Percent total organic carbon in sediment samples collected from Salton Sea, California, irrigation drains, October 2008 


\section{Conversion Factors}

\begin{tabular}{lll}
\hline \multicolumn{1}{c}{ Multiply } & By & \multicolumn{1}{c}{ To obtain } \\
\hline millimeter $(\mathrm{mm})$ & Length & \\
micrometer & 0.03937 & inch (in.) \\
& 0.0000393 & inch (in.) \\
\hline liter $(\mathrm{L})$ & Volume & \\
milliliter $(\mathrm{mL})$ & 33.82 & ounce, fluid (fl. oz) \\
& .034 & ounce, fluid (fl. oz) \\
\hline gram $(\mathrm{g})$ & Mass & ounce, avoirdupois (oz) \\
milligram $(\mathrm{mg})$ & 0.03527 & ounce (oz) \\
\hline
\end{tabular}

Temperature in degrees Celsius $\left({ }^{\circ} \mathrm{C}\right)$ may be converted to degrees Fahrenheit $\left({ }^{\circ} \mathrm{F}\right)$ as follows:

$$
{ }^{\circ} \mathrm{F}=\left(1.8 x^{\circ} \mathrm{C}\right)+32
$$

Concentrations of chemical constituents in water are given either in milligrams per liter (mg/L) or micrograms per liter $(\mu \mathrm{g} / \mathrm{L})$.

Concentrations of chemical constituents in solid materials are given in micrograms per gram $(\mu \mathrm{g} / \mathrm{g})$ dry weights. 


\title{
Total Selenium and Selenium Species in Irrigation Drain Inflows to the Salton Sea, California, October 2008 and January 2009
}

\author{
By Thomas W. May, Michael J. Walther, Michael K. Saiki, and William G. Brumbaugh
}

\section{Abstract}

This report presents the results for two sampling periods (October 2008 and January 2009) during a 4-year monitoring program to characterize selenium concentrations in selected irrigation drains flowing into the Salton Sea, California. Total selenium, selenium species (dissolved selenite, selenate, organoselenium), and total suspended solids were determined in water samples. Total selenium also was determined in water column particulates and in sediment, detritus, and biota that included algae, plankton, midge larvae (family, Chironomidae), and two fish species (western mosquitofish, Gambusia affinis, and sailfin molly, Poecilia latipinna). In addition, sediments were analyzed for percent total organic carbon and particle size. Mean total selenium concentrations in water for both sampling periods ranged from 1.00 to 33.6 micrograms per liter, predominately as selenate, which is typical of waters where selenium is leached out of selenium-containing marine shales and associated soils under alkaline and oxidizing conditions. Total selenium concentrations (micrograms per gram dry weight) ranged as follows: algae, 1.52 to 8.26 ; plankton, 0.79 to 3.66 ; midges, 2.68 to 50.6 ; fish, 3.09 to 30.4 ; detritus, 1.78 to 58.0 ; and sediment, 0.42 to 10.0 .

\section{Introduction}

Monitoring surveys are being conducted by the U.S. Geological Survey (USGS) for 4 years to provide a profile of selenium concentrations in selected irrigation drain inflows to the Salton Sea, California. To accomplish this goal, total selenium, selenium species (dissolved selenite, selenate, organoselenium), and total suspended solids were determined in water samples. Total selenium was measured in water column particulates and in sediment, detritus, and biota that included algae, plankton, midge larvae (family, Chironomidae), and two fish species (western mosquitofish, Gambusia affinis, and sailfin molly, Poecilia latipinna). In addition, sediments were analyzed for percent total organic carbon and particle size.
The results in this report were derived from samples collected during October 2008 and January 2009.

\section{Methods}

\section{Field Collection and Preservation}

The USGS sampling team used the laboratory at the U.S. Fish and Wildlife Service Sonny Bono Salton Sea National Wildlife Refuge (henceforth referred to as "the Refuge") for certain aspects of sample processing and for preparing samples for shipment during field trips to irrigation drains.

Unfiltered Water: Each water sample to be analyzed for total selenium was poured through a 1-millimeter (mm) polypropylene sieve attached to a 1-liter (L) precleaned borosilicate glass bottle. Upon collection, the water sample was acidified to less than $\mathrm{pH} 2$ with 6 normal $(\mathrm{N})$ hydrochloric acid $(\mathrm{HCl})$, chilled to approximately four degrees Celsius $\left(\sim 4{ }^{\circ} \mathrm{C}\right)$, and kept in the dark during transport to the USGS. Each water sample intended for analysis of total suspended solids (TSS) was poured through a 1-mm polypropylene sieve attached to a precleaned widemouth 1-L polypropylene bottle. The TSS samples were chilled $\left(\sim{ }^{\circ} \mathrm{C}\right)$ during transport to the USGS.

Filtered Water: Water for selenium speciation was filtered using a Geotech ${ }^{\circledR}$ peristaltic pump equipped with a standard pumphead and high-capacity 0.45 micrometer $(\mu \mathrm{m})$ filter capsule certified for trace-element background. All tubing was acid-cleaned silicone and a new length was used at each site and for the blank. At each site, $1 \mathrm{~L}$ of deionized (DI) water was filtered through the filter capsule followed by site water. The first 200 milliliters $(\mathrm{mL})$ of site water eluant were discarded, then $1 \mathrm{~L}$ of eluant was collected in an acid-cleaned 1-L borosilicate glass bottle, acidified, and stored as described earlier for unfiltered water.

Particulates: A polycarbonate Geotech ${ }^{\circledR} 142-\mathrm{mm}$ plate filter apparatus was used with a $142-\mathrm{mm} 0.4-\mu \mathrm{m}$ polycarbonate filter. At each site, $0.5 \mathrm{~L}$ of DI water was filtered through the plate filter, followed by up to $1 \mathrm{~L}$ of site water; after volume notation, the filtrate was discarded. Each filter was placed in 
a precleaned plastic petri dish $(150 \mathrm{~mm} \times 15 \mathrm{~mm})$ with the particulate side up and sealed with its corresponding cover for freezer storage and transport to the USGS. The plate filtration unit was rinsed with 0.1 percent nitric acid $\left(\mathrm{HNO}_{3}\right)$, followed by a DI water rinse after sampling was completed at each site.

Sediment: Five sampling points for sediment collection were identified along the length of each drain. At each sampling point, the uppermost 2 to $6 \mathrm{~cm}$ of sediment were collected with a stainless steel dredge. The dredge was cleared of mud and rinsed with site water while used within a drain. At a new site, the dredge was rinsed with DI water followed by site water before the first sample was collected. From each of the five sampling points, enough sediment to fill a $250-\mathrm{mL}$ container was collected and mixed to form a composite sample (1,250-mL total). An aliquot of this composite was then placed into a 120 - and a $500-\mathrm{mL}$ polypropylene container for each drain sampled. All containers were placed on ice in the field. Samples were chilled $\left(\sim 4{ }^{\circ} \mathrm{C}\right)$ during transport to the USGS.

Midge Larvae and Detritus: An insect sweep net was used to collect samples of midge larvae and detritus, which were then sorted and hand picked with plastic tweezers in a polypropylene sieve, and stored temporarily in a plastic foodstorage container on ice. After rinsing with DI water, samples were wrapped in plastic wrap, stored in separate plastic bags, and frozen.

Fish: Composite samples of western mosquitofish and sailfin molly were collected with seine nets and minnow traps; sampled fish from each site were stored temporarily in a plastic food-storage container on ice. Upon return to the Refuge laboratory, the whole-body fish were measured for standard length, weighed, and rinsed with DI water. Each fish composite sample $(\mathrm{n}=36)$ was wrapped in plastic wrap and placed into a plastic bag and frozen.

Algae and Plankton: Algae were collected from floating masses or scraped from sticks and rocks at each drain site and stored temporarily in a sealable plastic food-storage container on ice. Following collection, the material was rinsed with DI water, wrapped with plastic wrap, stored in a plastic bag, and frozen. Plankton was collected with a tow net and after draining site water, each sample was rinsed three times with DI water. The plankton and the DI rinsing water were placed in a 120 -mL polypropylene container. Collected samples were stored on ice in the field and frozen immediately upon return to the Refuge.

\section{Sampling History}

The irrigation drain monitoring samples collected by USGS personnel were received in six shipments by the Environmental Chemistry Branch Inorganic Section (henceforth referred to as "the laboratory") of the USGS shortly after collection to meet the 7 day holding time specified for TSS in water and the 14-day holding time for total organic carbon (TOC) in sediments.
The first set of samples was collected from October 15 to 17, 2008, received by the laboratory on October 21, 2008, and contained 17 TSS water samples, 26 water samples for total selenium, and 6 water samples for total dissolved selenium. The samples were assigned USGS batch number 1525 and USGS sample identification numbers 44164 to 44212 .

The second set of samples was collected from October 15 to 21,2008 , received by the laboratory on October 23, 2008, and contained 14 TSS water samples, 22 total selenium water samples, 11 total dissolved selenium water samples, 8 sediment samples for total selenium, 8 sediment samples for TOC and particle size analysis (PSA), and 15 particulate selenium filter samples. The samples were assigned USGS batch number 1530 and USGS sample identification numbers 44395 to 44472.

The third set of samples was received by the laboratory on October 24, 2008, and contained two filters to serve as blanks. The samples were assigned USGS batch number 1533 and USGS sample identification numbers 44485 to 44486.

The fourth set of samples was collected from October 15 to 21,2008 , received by the laboratory on November 5, 2008, and contained 42 fish samples, 21 algae samples, 21 midge samples, 21 detritus samples, and 21 plankton samples. The samples were assigned USGS batch number 1538 and USGS sample identification numbers 44570 to 44695 .

The fifth set of samples was collected from January 8 to 11,2009 , received by the laboratory on January 13, 2009, and contained 31 TSS water samples and 62 total selenium water samples. The samples were assigned USGS batch number 1553 and USGS sample identification numbers 45067 to 45159.

\section{Homogenization and Lyophilization}

Frozen fish samples were minced with a small ceramic knife before freeze drying. Particulates, biota, detritus, and sediment samples were lyophilized in a Virtis Genesis ${ }^{\circledR} 35 \mathrm{EL}$ freeze dryer and percent moisture was determined as part of the lyophilization process; however, percent moisture was not determined for plankton samples because the sample matrix included DI water. After lyophilization, all midge larvae, detritus, plankton, algae, and fish samples were homogenized by grinding with a glass rod against the container surface. Dried sediment was placed into a plastic bag, sealed, and then pulverized by using a rolling pin on the plastic bag to produce a coarse powder product. Dried filters containing particulates did not require any additional homogenization after freeze drying.

\section{Chemical Procedures}

Total Selenium in Water: Before analysis, all water samples were stored in the dark at $\sim 4{ }^{\circ} \mathrm{C}$. For the subsequent determination of total selenium in filtered and unfiltered samples, a $20-\mathrm{mL}$ aliquot of each acidified water sample was subjected 
to an $\mathrm{HNO}_{3}-$ magnesium nitrate $\left[\mathrm{Mg}\left(\mathrm{NO}_{3}\right)_{2}\right]$ ashing procedure, followed by treatment with $\mathrm{HCl}$. The ashing procedure consisted of three steps: boiling with $\mathrm{HNO}_{3}$ for solubilization and partial oxidation; ashing at $500{ }^{\circ} \mathrm{C}$ with $\mathrm{Mg}\left(\mathrm{NO}_{3}\right)_{2}$ to complete the oxidation and decompose remaining organic matter; and heating with $20 \mathrm{~mL}$ of 50 percent $(\mathrm{v} / \mathrm{v}) \mathrm{HCl}$ to dissolve the ash and chemically reduce selenium to the selenite $\left(\mathrm{Se}^{+4}\right)$ oxidation state required for detection by hydride generation atomic absorption spectrophotometry. Following reduction, digestates were diluted to $\sim 100 \mathrm{~mL}$ with DI water, yielding a final acid matrix of 10 percent $\mathrm{HCl}$.

Selenite + Selenate in Water: Ten $\mathrm{mL}$ of filtered water and $5 \mathrm{~mL}$ of concentrated $\mathrm{HCl}$ were placed in a $25-\mathrm{mL}$ borosilicate test tube and heated to about $130^{\circ} \mathrm{C}$ in a well incubator block for 3 to 4 hours. After cooling, the liquid was transferred into a $125-\mathrm{mL}$ polyethylene bottle, and the final volume was adjusted to $50 \mathrm{~mL}$ with DI water. The final matrix was 10 percent $\mathrm{HCl}$.

Filtered Particulates: A dried filter containing particulates was rolled up, cut into pieces, and the entire filter was put into a $100-\mathrm{mL}$ glass beaker. The filter was then subjected to the ashing procedure as described earlier for total selenium in water. The same procedure was conducted on clean filters, which served as blanks.

Biota, Detritus, and Sediment: An approximately 0.25gram (g) aliquant of each dried sample was subjected to a $\mathrm{HNO}_{3}-\mathrm{Mg}\left(\mathrm{NO}_{3}\right)_{2}$ ashing procedure, followed by $\mathrm{HCl}$ chemical reduction of selenate to selenite for the determination of selenium. The steps in the procedure were the same as those described above for total selenium in water. Digestates were diluted to about $100 \mathrm{~mL}$ with DI water, yielding a final acid matrix of 10 percent $\mathrm{HCl}$.

\section{Instrumental Analysis}

Total Selenium: Total selenium was determined in all ashed samples by flow injection hydride generation atomic absorption spectrophotometry (FIHGAAS). In this procedure, the digestate is mixed with an $\mathrm{HCl}$-carrier solution and then reduced by sodium tetrahydridoborate that has been stabilized with sodium hydroxide. Selenium in the sample is converted to volatile hydrogen selenide and transferred with argon carrier gas into a heated quartz cell mounted on an atomic absorption spectrophotometer for decomposition into atomic vapor and measurement.

Selenite in Water: An aliquot of each filtered water sample was analyzed directly by FIHGAAS after acidification to 10 percent $\mathrm{HCl}$.

Selenate and Selenite in Water: Samples prepared in this manner were analyzed directly by FIHGAAS to provide selenate + selenite concentrations. The selenate concentration was calculated by difference using the formula:

$$
\text { selenate }=(\text { selenate }+ \text { selenite })-\text { selenite } .
$$

Particulate Selenium in Water: Selenium associated with filtered particulates was determined by analyzing ashed filters by FIHGAAS. The mass of selenium in micrograms for the particulates was divided by the volume of water filtered for each drain site $(0.5$ or $1 \mathrm{~L})$ to produce a microgram per liter concentration.

Dissolved Organic Selenium in Water: Dissolved organic selenium was estimated using the following formula:

$$
\begin{gathered}
\text { dissolved organic selenium }=\text { total dissolved selenium }- \\
(\text { selenate }+ \text { selenite }) .
\end{gathered}
$$

Total dissolved selenium is defined as the analysis of filtered water for total selenium.

Total Suspended Solids: Upon arrival at the laboratory, all TSS samples were transferred to the Ecology Branch for TSS analysis. TSS were analyzed with methods recommended by the American Public Health Association (1998). Samples were brought to room temperature and mixed with a magnetic stirrer and subsequent manual inversions of the sample container. The sample was measured into a graduated cylinder, poured into a filtration apparatus, and filtered through a ProWeigh ${ }^{\circledR}$ glass fiber filter. The samples were prewashed three times in DI water, dried at $105^{\circ} \mathrm{C}$, and weighed to the nearest 0.1 milligram $(\mathrm{mg})$. Sample volume varied to yield a dried residue between 2.5 and $200 \mathrm{mg}$. For each volume of sample used, an equal volume of DI water also was filtered for a blank determination. After filtering, large or nonhomogeneous materials were removed from the filter and the filter was rinsed with three $10-\mathrm{mL}$ aliquots of DI water. Filters were then dried for at least 1 hour in a 103 to $105^{\circ} \mathrm{C}$ oven and cooled to room temperature in a desiccator, then filter and residue were weighed to the nearest $0.1 \mathrm{mg}$. Drying, cooling, and weighing of the filter were repeated until the weight difference was less than $(<) 4$ percent or $0.5 \mathrm{mg}$, whichever was less. The average of these weights was used to determine the constant weight of the filter and residue, which was then corrected for any weight gain or loss of the blank. After subtracting the filter weight, this blank-corrected dried residue in milligrams was divided by the sample volume in liters to yield TSS in milligrams per liter $(\mathrm{mg} / \mathrm{L})$.

Particle-Size Analysis: Sediment samples designated for PSA were transferred to the USGS Ecology Branch upon arrival. The method requires use of a Bouyoucos hydrometer, adapted from American Society for Testing and Materials (2003). Wet sediment was sieved through a 2-mm sieve to remove any particles larger than coarse sand and then dried at $60{ }^{\circ} \mathrm{C}$ using a convectional drying oven. Approximately 100 $\mathrm{g}$ of dried sediment was mixed with $250 \mathrm{~mL}$ of DI water and $100 \mathrm{~mL}$ of a $50 \mathrm{mg} / \mathrm{L}$ sodium hexametaphosphate solution. A stir bar was then added and the mixture was stirred with a magnetic stirring plate. After calibrating the hydrometer, the suspended sediment mixture was transferred to a sedimentation cylinder and the volume adjusted to $1 \mathrm{~L}$ with DI water. After allowing for thermal equilibration, the temperature was recorded. Cylinder contents were then thoroughly mixed, and 
the hydrometer was inserted into the suspension. The meniscus reading was taken after 30 seconds and the hydrometer was removed and dried. After 120 minutes, the hydrometer was reinserted and the meniscus read again. All hydrometer meniscus readings were corrected by adjusting +0.25 for each degree above $18^{\circ} \mathrm{C}$ and -0.25 for each degree below $18^{\circ} \mathrm{C}$.

Percent fractions were determined as follows:

grams sand $=$ sediment dry weight $-($ corrected 30 second reading - corrected calibration); percent sand $=$ grams sand/ sediment dry weight $\mathrm{x} 100$;

grams clay $=$ sediment dry weight $-($ corrected 120 minute reading - corrected calibration); percent clay $=$ grams clay $/$ sediment dry weight $\mathrm{x} 100$; andpercent silt $=100-$ (percent sand + percent clay).

Total Organic Carbon: TOC was determined with a Universal Instruments Corporation (UIC) Model 5014 Coulometer that determines carbon in any carbon dioxide $\left(\mathrm{CO}_{2}\right)$ containing gas stream (Universal Instruments Corporation, 1999). The coulometer is used as a detector with different carbon front-end units and can detect carbon in the range of 0.01 micrograms $(\mu \mathrm{g})$ to $100 \mathrm{mg}$. The coulometer cell is filled with a proprietary solution containing monoethanolamine and a colorimetric $\mathrm{pH}$ indicator. Platinum (cathode) and silver (anode) electrodes are positioned in the cell. The cell assembly is then placed in the coulometer cell compartment between a light source and a photodetector in the coulometer. As a $\mathrm{CO}_{2}$ gas stream passes into the cell, the $\mathrm{CO}_{2}$ is quantitatively absorbed and reacts with the monoethanolamine to form a titratable acid. This acid causes the color indicator to fade. A photodetector monitors the change in the color of the solution as a percent transmittance (percent $\mathrm{T}$ ). As the percent $\mathrm{T}$ increases, the titration current automatically is activated to electrochemically generate base at a rate proportional to the percent $\mathrm{T}$ (approximately 1,500 $\mu \mathrm{g}$ carbon/minute). When the solution returns to its original color (original percent $T$ ), the current stops.

For TOC analysis, total carbon (TC, $\mu \mathrm{g} / \mathrm{mg}$ ) and total inorganic carbon (TIC, $\mu \mathrm{g} / \mathrm{mg}$ ) are determined. Total carbon is determined by combustion of weighed sediments at $925^{\circ} \mathrm{C}$. In TIC analysis, weighed sediments are exposed to heated $2 \mathrm{~N}$ sulfuric acid. Any inorganic carbonates are chemically reduced to mineral components and $\mathrm{CO}_{2}$ gas. The gas is carried in high purity oxygen to the coulometer cell, where it is measured by the procedure described above. Percent TOC is calculated as follows:

$$
\text { Percent TOC }=[(\mathrm{TC}-\mathrm{TIC}) / \mathrm{TC}] \times 100
$$

\section{Quality Assurance}

Samples were processed through the preparative and analytical flow scheme in 11 analytical blocks for selenium, 2 blocks for TSS, and 1 block each for PSA and TOC. Each block was assigned a block initiation date (BID) used to identify samples and quality-control samples/materials prepared and analyzed collectively as a unit. For samples analyzed by atomic absorption for total selenium, predigestion quality control included digestion blanks, replicates, spikes, and reference solutions. Analytical quality-control for selenium included calibration verification solutions, replicate analyses, and analysis spikes. Quality control for the TSS, PSA, and TOC determinations included reference materials, duplicates, and replicates.

\section{Results}

Total Selenium: Total selenium concentrations [micrograms per liter, $(\mu \mathrm{g} / \mathrm{L})]$ in unfiltered water samples for the October 2008 samples are listed in table 1. Mean selenium concentrations were most elevated in water from Trifolium 22 drain (8.04), followed by P drain (7.07). The lowest mean selenium concentration was from San Felipe Wash drain (1.00). Data for the January 2009 samples are listed in table 2. Mean selenium concentrations were highest in Trifolium Storm drain (33.6), followed by Trifolium 18 drain (19.7), and Q drain (11.4). The lowest mean selenium concentration was from $U$ drain (1.26).

Total Dissolved Selenium and Selenium Species: Dissolved selenite, dissolved selenate, dissolved organic selenium, total dissolved selenium, and particulate selenium concentrations $(\mu \mathrm{g} / \mathrm{L})$ from filtered water samples collected during the October 2008 sampling are presented in table 3. The dissolved organic selenium fraction is assumed to include seleno-amino acids and dissolved seleno-peptides, $\operatorname{Se}(0)$ as a pseudo-dissolved microcolloid, and inorganic Se(-II) species (Cutter and Bruland, 1984). Speciation measurements revealed that selenium in the sampled drains exists predominately as selenate (61 to 93 percent) followed by selenite (4 to 27 percent), typical of waters where selenium is leached out of selenium containing marine shales and associated soils under alkaline and oxidizing conditions.

Total Suspended Solids: TSS concentrations (mg/L) in unfiltered water collected during the October 2008 and January 2009 samplings are presented in table 4 . TSS concentrations ranged from a high of 192 (T drain) to a low of 6.1 (Former Trifolium 20 drain) for the October 2008 collection, and a high of 216 (Vail 5 drain) to a low of 9.00 (Niland 4 drain) for the January 2009 collection.

Biota: Percent moisture and concentrations of selenium [micrograms per gram $(\mu \mathrm{g} / \mathrm{g})$ dry weight] in biota (algae, plankton, midge larvae, western mosquitofish, and sailfin molly) are presented in table 5. Selenium concentration ranges for each matrix were as follows: algae, 1.68 to 8.26; plankton, 0.79 to 3.66; midges, 2.68 to 50.6; and fish, 3.09 to 30.4 .

Detritus and Sediment: Percent moisture and selenium concentrations ( $\mu \mathrm{g} / \mathrm{g}$ dry weight) in detritus and sediment are presented in table 6 . Selenium in detritus ranged from 1.78 to 
Table 1. Total selenium concentrations in duplicates of unfiltered irrigation drain water samples, Salton Sea, California, October 2008.

[USGS, United States Geological Survey; ID, identification; Rep, field replicate; $\mu \mathrm{g} / \mathrm{L}$, microgram per liter; SD, standard deviation; ---, no data; <, less than; nc, not collected]

\begin{tabular}{|c|c|c|c|c|c|c|c|}
\hline \multirow[b]{2}{*}{ USGS ID } & \multirow[b]{2}{*}{ Field ID } & \multirow[b]{2}{*}{$\begin{array}{c}\text { Drain } \\
\text { name/ID }\end{array}$} & \multirow[b]{2}{*}{$\begin{array}{l}\text { Collection } \\
\text { date }\end{array}$} & \multicolumn{3}{|c|}{ Total selenium concentration } & \multirow[b]{2}{*}{ SD } \\
\hline & & & & $\begin{array}{l}\text { Rep } 1 \\
(\mu \mathrm{g} / \mathrm{L})\end{array}$ & $\begin{array}{l}\text { Rep } 2 \\
(\mu \mathrm{g} / \mathrm{L})\end{array}$ & $\begin{array}{l}\text { Mean } \\
(\mu \mathrm{g} / \mathrm{L})\end{array}$ & \\
\hline 44441 & BLANK-2 & --- & $10 / 23 / 08$ & $<0.15$ & --- & --- & --- \\
\hline 44442 & BLNDWATSE14 & --- & $10 / 16 / 08$ & 4.31 & --- & --- & --- \\
\hline 44181,44182 & NLD1WATSE14 & Niland 1 & $10 / 16 / 08$ & 1.53 & 1.53 & 1.53 & 0.00 \\
\hline 44183,44184 & NLD2WATSE14 & Niland 2 & $10 / 16 / 08$ & 2.17 & 2.19 & 2.18 & 0.02 \\
\hline 44185,44186 & NLD3WATSE14 & Niland 3 & $10 / 16 / 08$ & 1.87 & 1.92 & 1.89 & 0.03 \\
\hline 44187,44188 & NLD4WATSE14 & Niland 4 & $10 / 16 / 08$ & 2.26 & 2.39 & 2.33 & 0.09 \\
\hline 44203,44204 & PUMCWATSE14 & Pumice & $10 / 17 / 08$ & 4.90 & 4.86 & 4.88 & 0.03 \\
\hline 44197,44198 & QQQQWATSE14 & Q & $10 / 17 / 08$ & 3.67 & 3.79 & 3.73 & 0.09 \\
\hline 44195,44196 & RRRRWATSE14 & $\mathrm{R}$ & $10 / 17 / 08$ & 2.13 & 2.01 & 2.07 & 0.08 \\
\hline 44193,44194 & SSSSWATSE14 & $\mathrm{S}$ & $10 / 17 / 08$ & 2.72 & 2.65 & 2.68 & 0.05 \\
\hline 44448,44449 & SFWHWATSE14 & San Felipe Wash & $10 / 18 / 08$ & 0.98 & 1.03 & 1.00 & 0.03 \\
\hline$n c^{1}$ & TTTTWATSE14 & $\mathrm{T}$ & --- & --- & --- & --- & --- \\
\hline 44452,44453 & TR01WATSE14 & Trifolium 1 & $10 / 21 / 08$ & 4.96 & 4.97 & 4.97 & 0.01 \\
\hline 44456,44457 & TR12WATSE14 & Trifolium 12 & $10 / 21 / 08$ & 4.75 & 4.75 & 4.75 & 0.00 \\
\hline 44454,44455 & TR13WATSE14 & Trifolium 13 & $10 / 19 / 08$ & 3.50 & 3.59 & 3.54 & 0.06 \\
\hline 44446,44447 & TR22WATSE14 & Trifolium 22 & $10 / 18 / 08$ & 8.03 & 8.05 & 8.04 & 0.01 \\
\hline 44450,44451 & TR23WATSE14 & Trifolium 23 & $10 / 18 / 08$ & 3.77 & 3.83 & 3.80 & 0.04 \\
\hline 44458,44459 & TRSTWATSE14 & Trifolium Storm & $10 / 21 / 08$ & 3.15 & 3.06 & 3.10 & 0.06 \\
\hline 44191,44192 & UUUUWATSE14 & $\mathrm{U}$ & $10 / 16 / 08$ & 1.70 & 1.66 & 1.68 & 0.03 \\
\hline 44201,44202 & VL05WATSE14 & Vail 5 & $10 / 17 / 08$ & 4.73 & 5.02 & 4.88 & 0.20 \\
\hline 44189,44190 & WWWWWATSE14 & $\mathrm{W}$ & $10 / 16 / 08$ & 4.39 & 4.40 & 4.40 & 0.002 \\
\hline $\mathrm{nc}^{1}$ & ZSPLWATSE14 & Z Spill & --- & --- & --- & --- & --- \\
\hline
\end{tabular}

${ }^{1}$ Drain was one of seven selected for intensive sampling (see table 3 ). 
Table 2. Total selenium concentrations in duplicates of unfiltered irrigation drain water samples, Salton Sea, California, January 2009.

[USGS, United States Geological Survey; ID, identification; Rep, field replicate; $\mu \mathrm{g} / \mathrm{L}$, micrograms per liter; SD, standard deviation; <, less than]

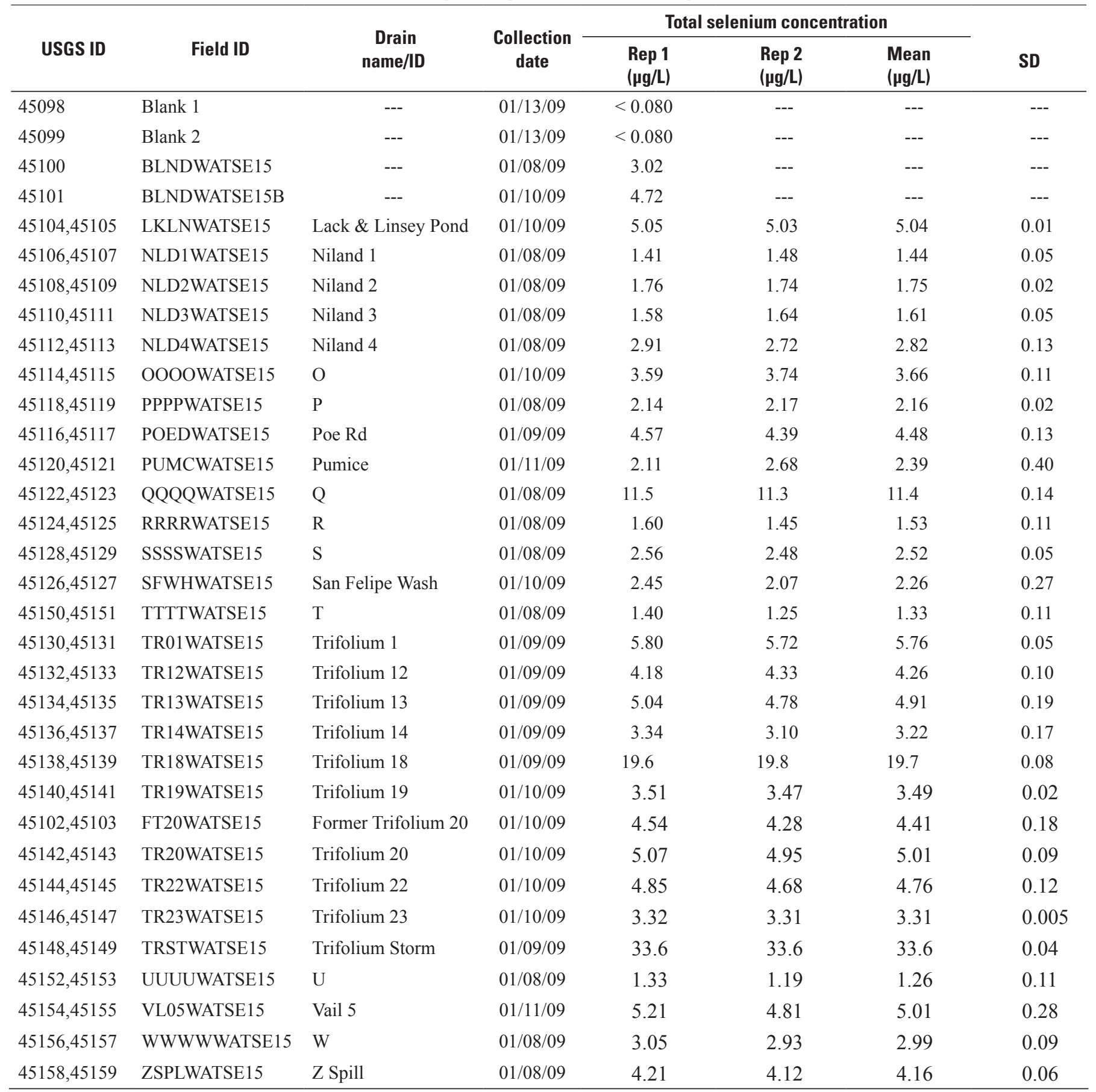


Table 3. Total dissolved selenium, dissolved selenium species, and particulate selenium concentrations in filtered irrigation drain water samples, Salton Sea, California, October 2008.

[USGS, United States Geological Survey; ID, identification; Rep, replicate; [Se03]-2, selenite; [Se04]-2, selenate; Se, selenium; $\mu \mathrm{g} / \mathrm{L}$, micrograms per liter; ---, no data; <, less than]

\begin{tabular}{|c|c|c|c|c|c|c|c|c|c|c|}
\hline USGS ID & Field ID & $\begin{array}{c}\text { Drain } \\
\text { name/ID }\end{array}$ & Rep & $\begin{array}{l}\text { Collection } \\
\text { fate }\end{array}$ & $\begin{array}{c}\text { Dissolved } \\
\text { [Se03]-2 } \\
(\mu \mathrm{g} / \mathrm{L})\end{array}$ & $\begin{array}{l}\text { 'Calculated } \\
\text { dissolved } \\
\text { [Se04]-2 } \\
(\mu \mathrm{g} / \mathrm{L})\end{array}$ & $\begin{array}{c}{ }^{2} \text { Calculated } \\
\text { dissolved } \\
\text { organic Se } \\
(\mu \mathrm{g} / \mathrm{L})\end{array}$ & $\begin{array}{l}\text { Measured } \\
\text { total dis- } \\
\text { solved Se } \\
(\mu \mathrm{g} / \mathrm{L})\end{array}$ & $\begin{array}{c}{ }^{3} \text { Measured } \\
\text { particulate Se } \\
(\mu \mathrm{g} / \mathrm{L})\end{array}$ & $\begin{array}{c}{ }^{4} \text { Calculated } \\
\text { total Se } \\
(\mu \mathrm{g} / \mathrm{L})\end{array}$ \\
\hline 44463 & BLNKWADSE14 & --- & 1 & $10 / 19 / 08$ & $<0.072$ & $<0.11$ & --- & $<0.38$ & $<0.004$ & --- \\
\hline 44464 & BLNKWADSE14B & --- & 2 & $10 / 19 / 08$ & $<0.072$ & $<0.11$ & --- & $<0.38$ & --- & --- \\
\hline 44462 & BLNDWADSE14 & --- & --- & $10 / 16 / 08$ & 0.63 & 3.65 & 0.11 & 4.39 & 0.103 & 4.49 \\
\hline 44207 & OOOOWADSE14 & $\mathrm{O}$ & 1 & $10 / 15 / 08$ & 0.71 & 3.39 & 0.10 & 4.20 & 0.043 & 4.24 \\
\hline 44208 & OOOOWADSE14B & $\mathrm{O}$ & 2 & $10 / 15 / 08$ & 0.72 & 3.53 & 0.00 & 4.22 & 0.063 & 4.28 \\
\hline 44465 & POEDWADSE14 & Poe Rd & 1 & $10 / 20 / 08$ & 1.81 & 7.40 & 0.94 & 10.1 & 0.100 & 10.25 \\
\hline 44466 & POEDWADSE14B & Poe Rd & 2 & $10 / 20 / 08$ & 1.96 & 7.83 & 0.36 & 10.2 & 0.065 & 10.22 \\
\hline 44209 & TTTTWADSE14 & $\mathrm{T}$ & 1 & $10 / 17 / 08$ & 0.35 & 1.06 & 0.22 & 1.63 & 0.123 & 1.75 \\
\hline 44210 & TTTTWADSE14B & $\mathrm{T}$ & 2 & $10 / 17 / 08$ & 0.34 & 1.06 & 0.11 & 1.50 & 0.091 & 1.59 \\
\hline 44467 & TR14WADSE14 & Trifolium 14 & 1 & $10 / 19 / 08$ & 0.30 & 7.7 & 0.21 & 8.21 & 0.044 & 8.26 \\
\hline 44468 & TR14WADSE14B & Trifolium 14 & 2 & $10 / 19 / 08$ & 0.35 & 7.1 & 0.22 & 7.67 & 0.054 & 7.72 \\
\hline 44469 & TR18WADSE14 & Trifolium 18 & 1 & $10 / 21 / 08$ & 1.52 & 12.8 & 0.49 & 14.8 & 0.051 & 14.8 \\
\hline 44470 & TR18WADSE14B & Trifolium 18 & 2 & $10 / 21 / 08$ & 1.55 & 12.9 & 0.31 & 14.8 & 0.027 & 14.8 \\
\hline 44471 & TR20WADSE14 & Trifolium 20 & 1 & $10 / 18 / 08$ & 0.56 & 1.45 & 0.01 & 2.01 & 0.070 & 2.08 \\
\hline 44472 & TR20WADSE14B & Trifolium 20 & 2 & $10 / 18 / 08$ & 0.55 & 1.44 & 0.22 & 2.22 & 0.085 & 2.30 \\
\hline 44211 & ZSPLWADSE14 & Z Spill & 1 & $10 / 16 / 08$ & 0.57 & 3.66 & 0.18 & 4.41 & 0.108 & 4.52 \\
\hline 44212 & ZSPLWADSE14B & Z Spill & 2 & $10 / 16 / 08$ & 0.58 & 3.74 & 0.04 & 4.37 & 0.095 & 4.46 \\
\hline
\end{tabular}


Table 4. Total suspended solids concentrations in unfiltered Salton Sea, California, irrigation drain water samples, October 2008 and January 2009.

[USGS, United States Geological Survey; ID, identification; TSS, total suspended solids; mg/L, milligram per liter; bold and italicized values are less than the method quantitation limit and have high uncertainty]

\begin{tabular}{|c|c|c|c|c|c|}
\hline \multirow[b]{2}{*}{ Field ID } & \multirow{2}{*}{$\begin{array}{c}\text { Drain } \\
\text { name/ID }\end{array}$} & \multicolumn{2}{|c|}{ October, 2008} & \multicolumn{2}{|c|}{ January, 2009} \\
\hline & & USGS ID & $\begin{array}{c}\text { TSS } \\
\text { (mg/L) }\end{array}$ & USGS ID & $\begin{array}{c}\text { TSS } \\
\text { (mg/L) }\end{array}$ \\
\hline BLNDWATSSA & Blind $\mathrm{A}$ & 44178 & 99. & 45067 & 32. \\
\hline BLNDWATSSB & Blind B & 44407 & 29. & 45068 & 40. \\
\hline LKLNWATSS & Lack \& Linsey Pond & 44180 & 93. & 45070 & 46. \\
\hline NLD1WATSS & Niland 1 & 44164 & 83. & 45071 & 36. \\
\hline NLD2WATSS & Niland 2 & 44165 & 20. & 45072 & 41. \\
\hline NLD3WATSS & Niland 3 & 44166 & 64. & 45073 & 43. \\
\hline NLD4WATSS & Niland 4 & 44167 & 47. & 45074 & 9.0 \\
\hline OOOOWATSS & $\mathrm{O}$ & 44176 & 118. & 45075 & 35. \\
\hline PPPPWATSS & $\mathrm{P}$ & 44175 & 86. & 45077 & 115. \\
\hline POEDWATSS & Poe Rd & 44400 & 77. & 45076 & 179. \\
\hline PUMCWATSS & Pumice & 44177 & 151. & 45078 & 99. \\
\hline QQQQWATSS & $\mathrm{Q}$ & 44174 & 28 & 45079 & 33. \\
\hline RRRRWATSS & $\mathrm{R}$ & 44173 & 87. & 45080 & 59. \\
\hline SSSSWATSS & $\mathrm{S}$ & 44172 & 92. & 45082 & 48. \\
\hline SFWHWATSS & San Felipe Wash & 44397 & 44. & 45081 & 13. \\
\hline TTTTWATSS & $\mathrm{T}$ & 44171 & 192. & 45093 & 54. \\
\hline TR01WATSS & Trifolium 1 & 44408 & 19. & 45083 & 66. \\
\hline TR12WATSS & Trifolium 12 & 44404 & 33. & 45084 & 213. \\
\hline TR13WATSS & Trifolium 13 & 44403 & 40. & 45085 & 84. \\
\hline TR14WATSS & Trifolium 14 & 44406 & 94. & 45086 & 55. \\
\hline TR18WATSS & Trifolium 18 & 44399 & 7.2 & 45087 & 23. \\
\hline TR19WATSS & Trifolium 19 & 44401 & 16. & 45088 & 40. \\
\hline FT20WATSS & Former Trifolium 20 & 44395 & 6.1 & 45069 & 43. \\
\hline TR20WATSS & Trifolium 20 & 44402 & 78. & 45089 & 66. \\
\hline TR22WATSS & Trifolium 22 & 44396 & 21. & 45090 & 62. \\
\hline TR23WATSS & Trifolium 23 & 44398 & 28. & 45091 & 114. \\
\hline TRSTWATSS & Trifolium Storm & 44405 & 17. & 45092 & 186. \\
\hline UUUUWATSS & $\mathrm{U}$ & 44170 & 40. & 45094 & 28. \\
\hline VLO5WATSS & Vail 5 & 44179 & 31. & 45095 & 216. \\
\hline WWWWWATSS & $\mathrm{W}$ & 44169 & 112. & 45096 & 153. \\
\hline ZSPLWATSS & Z Spill & 44168 & 89. & 45097 & 45. \\
\hline
\end{tabular}

${ }^{1}$ Trifolium 1 drain was dry at time of collection. 
Table 5. Selenium concentrations in biota samples collected from Salton Sea, California, irrigation drains, 0ctober 2008.

[USGS, United States Geological Survey; ID, identification; $\mu \mathrm{g} / \mathrm{g}$, microgram per gram; ---, no data]

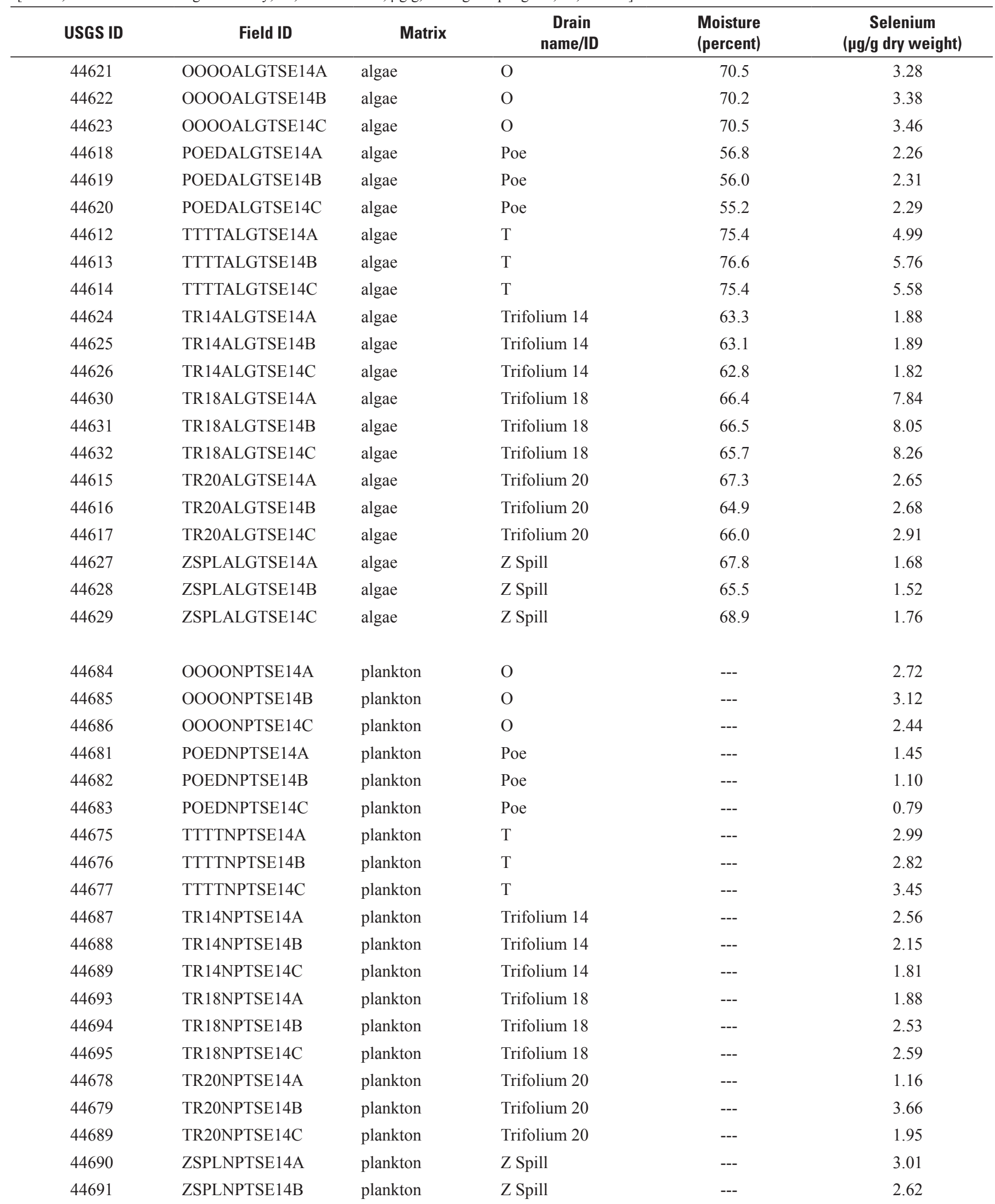


Table 5. Selenium concentrations in biota samples collected from Salton Sea, California, irrigation drains, October 2008.Continued

[USGS, United States Geological Survey; ID, identification; $\mu \mathrm{g} / \mathrm{g}$, microgram per gram; ---, no data]

\begin{tabular}{|c|c|c|c|c|c|}
\hline USGS ID & Field ID & Matrix & $\begin{array}{c}\text { Drain } \\
\text { name/ID }\end{array}$ & $\begin{array}{l}\text { Moisture } \\
\text { (percent) }\end{array}$ & $\begin{array}{c}\text { Selenium } \\
\text { ( } \mu \mathrm{g} / \mathrm{g} \text { dry weight) }\end{array}$ \\
\hline 44692 & ZSPLNPTSE14C & plankton & Z Spill & --- & 2.45 \\
\hline 44643 & OOOOCHITSE14B & midge & $\mathrm{O}$ & 82.0 & 2.68 \\
\hline 44644 & OOOOCHITSE14C & midge & $\mathrm{O}$ & 81.5 & 2.97 \\
\hline 44641 & POEDCHITSE14C & midge & Poe & 84.0 & 18.2 \\
\hline 44633 & TTTTCHITSE14A & midge & $\mathrm{T}$ & 81.3 & 6.37 \\
\hline 44634 & TTTTCHITSE14B & midge & $\mathrm{T}$ & 80.8 & 6.66 \\
\hline 44635 & TTTTCHITSE14C & midge & $\mathrm{T}$ & 81.6 & 6.43 \\
\hline 44651 & TR18CHITSE14A & midge & Trifolium 18 & 84.6 & 44.2 \\
\hline 44652 & TR18CHITSE14B & midge & Trifolium 18 & 84.3 & 44.0 \\
\hline 44653 & TR18CHITSE14C & midge & Trifolium 18 & 85.0 & 50.6 \\
\hline 44636 & TR20CHITSE14A & midge & Trifolium 20 & 82.0 & 6.59 \\
\hline 44637 & TR20CHITSE14B & midge & Trifolium 20 & 80.4 & 6.09 \\
\hline 44638 & TR20CHITSE14C & midge & Trifolium 20 & 82.7 & 6.47 \\
\hline 44648 & ZSPLCHITSE14A & midge & Z Spill & 79.4 & 4.15 \\
\hline 44649 & ZSPLCHITSE14B & midge & Z Spill & 79.2 & 3.63 \\
\hline 44650 & ZSPLCHITSE14C & midge & Z Spill & 77.0 & 3.78 \\
\hline 44593 & OOOOSLMTSE14C & sailfin molly & $\mathrm{O}$ & 78.8 & 3.71 \\
\hline 44582 & POEDGMBTSE14A & gambusia & Poe & 77.2 & 16.6 \\
\hline 44583 & POEDGMBTSE14B & gambusia & Poe & 76.6 & 15.2 \\
\hline 44584 & POEDGMBTSE14C & gambusia & Poe & 77.3 & 13.2 \\
\hline 44585 & POEDSLMTSE14A & sailfin molly & Poe & 78.8 & 16.0 \\
\hline 44586 & POEDSLMTSE14B & sailfin molly & Poe & 78.9 & 17.2 \\
\hline 44587 & POEDSLMTSE14C & sailfin molly & Poe & 77.8 & 15.2 \\
\hline 44570 & TTTTGMBTSE14A & gambusia & $\mathrm{T}$ & 74.8 & 6.23 \\
\hline 44571 & TTTTGMBTSE14B & gambusia & $\mathrm{T}$ & 75.1 & 6.07 \\
\hline 44572 & TTTTGMBTSE14C & gambusia & $\mathrm{T}$ & 75.3 & 6.08 \\
\hline 44573 & TTTTSLMTSE14A & sailfin molly & $\mathrm{T}$ & 75.8 & 5.14 \\
\hline 44574 & TTTTSLMTSE14B & sailfin molly & $\mathrm{T}$ & 76.4 & 6.44 \\
\hline 44575 & TTTTSLMTSE14C & sailfin molly & $\mathrm{T}$ & 75.7 & 5.31 \\
\hline 44594 & TR14GMBTSE14A & gambusia & Trifolium 14 & 77.7 & 4.07 \\
\hline
\end{tabular}


Table 5. Selenium concentrations in biota samples collected from Salton Sea, California, irrigation drains, October 2008. Continued

[USGS, United States Geological Survey; ID, identification; $\mu \mathrm{g} / \mathrm{g}$, microgram per gram; ---, no data]

\begin{tabular}{|c|c|c|c|c|c|}
\hline USGS ID & Field ID & Matrix & $\begin{array}{c}\text { Drain } \\
\text { name/ID }\end{array}$ & $\begin{array}{l}\text { Moisture } \\
\text { (percent) }\end{array}$ & $\begin{array}{c}\text { Selenium } \\
\text { ( } \mu \mathrm{g} / \mathrm{g} \text { dry weight) }\end{array}$ \\
\hline 44595 & TR14GMBTSE14B & gambusia & Trifolium 14 & 78.2 & 4.54 \\
\hline 44597 & TR14SLMTSE14A & sailfin molly & Trifolium 14 & 75.9 & 4.59 \\
\hline 44598 & TR14SLMTSE14B & sailfin molly & Trifolium 14 & 76.1 & 4.65 \\
\hline 44607 & TR18GMBTSE14B & gambusia & Trifolium 18 & 75.4 & 17.8 \\
\hline 44608 & TR18GMBTSE14C & gambusia & Trifolium 18 & 75.7 & 19.2 \\
\hline 44609 & TR18SLMTSE14A & sailfin molly & Trifolium 18 & 78.8 & 30.4 \\
\hline 44610 & TR18SLMTSE14B & sailfin molly & Trifolium 18 & 77.9 & 25.3 \\
\hline 44578 & TR20GMBTSE14C & gambusia & Trifolium 20 & 76.5 & 6.13 \\
\hline 44579 & TR20SLMTSE14A & sailfin molly & Trifolium 20 & 76.3 & 7.57 \\
\hline 44580 & TR20SLMTSE14B & sailfin molly & Trifolium 20 & 76.7 & 7.70 \\
\hline 44581 & TR20SLMTSE14C & sailfin molly & Trifolium 20 & 75.4 & 7.14 \\
\hline 44600 & ZSPLGMBTSE14A & gambusia & Z Spill & 77.6 & 6.77 \\
\hline 44601 & ZSPLGMBTSE14B & gambusia & Z Spill & 79.1 & 6.61 \\
\hline 44602 & ZSPLGMBTSE14C & gambusia & Z Spill & 79.4 & 6.18 \\
\hline 44603 & ZSPLSLMTSE14A & sailfin molly & Z Spill & 75.9 & 3.93 \\
\hline 44604 & ZSPLSLMTSE14B & sailfin molly & Z Spill & 76.4 & 4.84 \\
\hline
\end{tabular}


Table 6. Selenium concentrations in detritus and sediment samples collected from Salton Sea, California, irrigation drains, October 2008.

[USGS, United States Geological Survey; ID, identification; $\mu \mathrm{g} / \mathrm{g}$, micrograms per gram]

\begin{tabular}{|c|c|c|c|c|c|}
\hline USGS ID & Field ID & Matrix & $\begin{array}{c}\text { Drain } \\
\text { name/ID }\end{array}$ & $\begin{array}{l}\text { Moisture } \\
\text { (percent) }\end{array}$ & $\begin{array}{c}\text { Selenium } \\
\text { ( } \mu \mathrm{g} / \mathrm{g} \text { dry weight) }\end{array}$ \\
\hline 44663 & OOOODETTSE14A & detritus & $\mathrm{O}$ & 86.3 & 3.82 \\
\hline 44664 & OOOODETTSE14B & detritus & $\mathrm{O}$ & 85.7 & 4.85 \\
\hline 44665 & OOOODETTSE14C & detritus & $\mathrm{O}$ & 85.9 & 6.42 \\
\hline 44660 & POEDDETTSE14A & detritus & Poe & 74.4 & 7.10 \\
\hline 44661 & POEDDETTSE14B & detritus & Poe & 75.3 & 7.09 \\
\hline 44662 & POEDDETTSE14C & detritus & Poe & 71.8 & 6.59 \\
\hline 44654 & TTTTDETTSE14A & detritus & $\mathrm{T}$ & 77.6 & 2.52 \\
\hline 44655 & TTTTDETTSE14B & detritus & $\mathrm{T}$ & 77.2 & 1.78 \\
\hline 44656 & TTTTDETTSE14C & detritus & $\mathrm{T}$ & 79.6 & 2.22 \\
\hline 44666 & TR14DETTSE14A & detritus & Trifolium 14 & 80.7 & 9.86 \\
\hline 44667 & TR14DETTSE14B & detritus & Trifolium 14 & 82.1 & 5.14 \\
\hline 44668 & TR14DETTSE14C & detritus & Trifolium 14 & 80.6 & 6.42 \\
\hline 44672 & TR18DETTSE14A & detritus & Trifolium 18 & 82.4 & 39.7 \\
\hline 44673 & TR18DETTSE14B & detritus & Trifolium 18 & 83.8 & 27.4 \\
\hline 44674 & TR18DETTSE14C & detritus & Trifolium 18 & 80.5 & 58.0 \\
\hline 44657 & TR20DETTSE14A & detritus & Trifolium 20 & 79.0 & 3.94 \\
\hline 44658 & TR20DETTSE14B & detritus & Trifolium 20 & 77.6 & 12.4 \\
\hline 44659 & TR20DETTSE14C & detritus & Trifolium 20 & 79.2 & 4.07 \\
\hline 44669 & ZSPLDETTSE14A & detritus & Z Spill & 83.2 & 4.00 \\
\hline 44670 & ZSPLDETTSE14B & detritus & Z Spill & 82.2 & 3.14 \\
\hline 44671 & ZSPLDETTSE14C & detritus & Z Spill & 79.6 & 3.57 \\
\hline 44424 & BLNDSDTSE14 & sediment & Blind & 65.4 & 9.95 \\
\hline 44421 & OOOOSDTSE14 & sediment & $\mathrm{O}$ & 48.7 & 0.84 \\
\hline 44418 & POEDSDTSE14 & sediment & Poe & 23.1 & 0.42 \\
\hline 44422 & TTTTSDTSE14 & sediment & $\mathrm{T}$ & 50.6 & 0.72 \\
\hline 44420 & TR14SDTSE14 & sediment & Trifolium 14 & 50.7 & 1.90 \\
\hline 44419 & TR18SDTSE14 & sediment & Trifolium 18 & 65.8 & 10.0 \\
\hline 44417 & TR20SDTSE14 & sediment & Trifolium 20 & 30.9 & 1.10 \\
\hline 44423 & ZSPLSDTSE14 & sediment & Z Spill & 42.3 & 0.65 \\
\hline
\end{tabular}


58.0 and from 0.42 to 10.0 in sediment. The particle size analyses of sediments, expressed as percent sand, silt, and clay, are presented in table 7. Percent sand ranged from 14 to 76; percent silt from 15 to 57; and percent clay from 7.5 to 50 . Percent TOC in sediments is given in table 8 and ranged from 0.2 to 1.5 .

\section{Quality Control Results}

Calibration Verification: During the selenium determinations, a calibration verification solution (Spex Claritas PPT ${ }^{\circledR}$; Cat No. CLSe2-2Y) was analyzed at the beginning and end of each analytical run. Calibration was considered acceptable if the check solution was within plus or minus 10 percent of the actual concentration $(3 \mu \mathrm{g} / \mathrm{L})$, which was achieved during all analyses.

Reference Materials: Recoveries of selenium from QC Plus ${ }^{+}$Trace Metals Quality Control Standard [n=7
(7 samples)] and National Institute of Standards and Technology (NIST) Standard Reference Material (SRM) 1643e Trace Elements in Water $(n=3)$ averaged 103 percent. The recoveries of selenium from National Research Council of Canada (NRCC) SRM PACS-1 marine sediment ( $\mathrm{n}=1$ ) was 100 percent. The International Atomic Energy Agency (IAEA) copepod reference material MA-A-1 $(n=2)$ and the Institute for Reference Materials and Measurements Certified Reference Material (CRM) 414 Trace Elements in Plankton $(n=2)$ all exhibited selenium recoveries of 100 percent. Recoveries of selenium in NRCC CRM DORM-2 dogfish muscle $(n=1)$ and IAEA CRM 407 whole-body fish $(n=1)$ were 100 and 91 percent, respectively. Recoveries of TSS from a TSS reference solution (Environmental Resource Associates Hardness Wastewater Standard 507; $n=5$ ) averaged 101 percent. The recovery of total carbon from a carbon reference material (Environmental Resource Associates Nutrients in Soil 542; $\mathrm{n}=1$ ) was 100 percent. Recoveries of percent sand, silt, and clay from a CERC research sediment material ranged from 79 to 99 percent.

Table 7. Particle size distributions in sediment samples collected from Salton Sea, California, irrigation drains, 0 ctober 2008.

[USGS, United States Geological Survey; ID, identification; >, greater than; mm, millimeter]

\begin{tabular}{|c|c|c|c|c|c|c|}
\hline \multirow[b]{2}{*}{ USGS ID } & \multirow[b]{2}{*}{ Field ID } & \multirow{2}{*}{$\begin{array}{c}\text { Drain } \\
\text { name/ID }\end{array}$} & \multicolumn{4}{|c|}{ Particle size category } \\
\hline & & & $\begin{array}{c}>2 \mathrm{~mm} \\
\text { (percent) }\end{array}$ & $\begin{array}{c}\text { Sand } \\
\text { (percent) }\end{array}$ & $\begin{array}{c}\text { Silt } \\
\text { (percent) }\end{array}$ & $\begin{array}{c}\text { Clay } \\
\text { (percent) }\end{array}$ \\
\hline 44416 & BLNDSDTOC14 & Blind & 0. & 55. & 37. & 7. \\
\hline 44413 & OOOOSDTOC14 & $\mathrm{O}$ & 0. & 24. & 37. & 39. \\
\hline 44410 & POEDSDTOC14 & Poe $\mathrm{Rd}$ & 0. & 76. & 15. & 10. \\
\hline 44414 & TTTTSDTOC14 & $\mathrm{T}$ & 0. & 15. & 36. & 50. \\
\hline 44412 & TR14SDTOC14 & Trifolium 14 & 0. & 14. & 57. & 29. \\
\hline 44411 & TR18SDTOC14 & Trifolium 18 & 0. & 55. & 37. & 8. \\
\hline 44409 & TR20SDTOC14 & Trifolium 20 & 1. & 47. & 27. & 25. \\
\hline 44415 & ZSPLSDTOC14 & Z Spill & 7. & 15. & 33. & 45. \\
\hline
\end{tabular}

Table 8. Percent total organic carbon in sediment samples collected from Salton Sea, California, irrigation drains, 0 ctober 2008.

[USGS, United States Geological Survey; ID, identification]

\begin{tabular}{cllr}
\hline USGS ID & Field ID & \multicolumn{1}{c}{$\begin{array}{c}\text { Drain } \\
\text { name/ID }\end{array}$} & $\begin{array}{c}\text { Total organic carbon } \\
\text { (percent) }\end{array}$ \\
\hline 42216 & BLNDSDTOC14 & Blind & 1.5 \\
42209 & TR20SDTOC14 & Trifolium 20 & 0.7 \\
42210 & POEDSDTOC14 & Poe Rd. & 0.2 \\
42211 & TR18SDTOC14 & Trifolium 18 & 1.3 \\
42212 & TR14SDTOC14 & Trifolium 14 & 1.1 \\
42213 & OOOOSDTOC14 & O & 0.6 \\
42214 & TTTTSDTOC14 & T & 0.5 \\
42215 & ZSPLSDTOC14 & Z Spill & 1.2 \\
\hline
\end{tabular}


Analytical and Method Precision: Instrumental precision for selenium as determined by repeated analysis of a standard throughout the run for each block $(n=11)$ was less than 5 percent relative standard deviation (RSD). Relative percent differences (RPDs) between field duplicates $(n=73)$ of either unfiltered or filtered water samples analyzed for selenium or selenium species mostly were $\leq$ (less than or equal) $12(n=70)$, but two of these duplicates exhibited greater RPDs of 15 and 24. Both of these RPDs were associated with relatively low selenium concentrations $(<5 \mu \mathrm{g} / \mathrm{L})$. RSDs for triplicate field samples of detritus $(n=7)$, algae $(n=7)$, plankton $(n=7)$, midge larvae $(n=7)$, and whole-body fish $(n=14)$ analyzed for selenium were as follows: algae, 1.0 to 7.5 percent; plankton, 11 to 56 percent; detritus, 4.2 to 71 percent; midge larvae, 2.4 to 9.1 percent; and whole-body fish, 1.5 to 15 percent. Once again, many of the greatest RSDs were associated with low selenium concentrations, but in some instances greater variation apparently reflected greater natural variation of selenium in certain sample matrices, for example detritus and plankton. Laboratory method precision for triplicate $(n=18)$ preparation and analysis of samples for selenium was $<10$ percent RSD. Instrumental precision was based on duplicate analysis of sample digestates from each sample matrix, which resulted in RPDs $<2$ percent. Duplicate analysis of water samples for TSS $(n=4)$ resulted in RPDs ranging from 1.0 to 21 percent, whereas triplicate analysis for TSS $(n=3)$ resulted in RSDs $<5$ percent. The duplicate analysis of a drain sediment for PSA resulted in RPDs $<7$ percent for the fractions.. Triplicate analyses of a drain sediment for PSA resulted in RSDs $\leq 14$ percent for the fractions. The duplicate analysis of six drain sediments for TOC resulted in RPDs 6.9 to 22 percent for five drains, but one higher RPD of 82 percent, presumably because of a low TOC level ( $\leq 1$ percent) and the natural heterogeneity of the drain sediment. A replicate analysis of one drain sediment resulted in a RSD of 27 percent.

Spikes: Recoveries of selenium [selenite $\left(\mathrm{Se}^{+4}\right)$, selenate $\left(\mathrm{Se}^{+6}\right)$, or selenomethionine] spiked into a filter blanks $(\mathrm{n}=1)$ and water samples $(n=21)$ ranged from 89 to 106 percent, averaging 98 percent. Recoveries of selenium spiked into sediment $(n=2)$, detritus $(n=4)$, and biota $(n=10)$ ranged from 92 to 103 percent, averaging 99 percent. Recoveries of selenium spikes added to water during analysis $(n=17)$ ranged from 97 to 110 percent, averaging 102 percent. Analysis spikes of sediment $(n=1)$, filtered particulates $(n=2)$, detritus $(n=2)$, and biota $(\mathrm{n}=10)$ ranged from 98 to 106 percent, averaging 101 percent.

Blank Equivalent Concentrations: Blank equivalent concentrations (BECs) were computed for selenium for each matrix and for TSS blanks analyzed with each set of drain water samples. BECs for water and filter particulates were less than their respective method detection limits (MDLs). BECs $(\mu \mathrm{g} / \mathrm{g})$ for detritus, sediment, and all biota were greater than their respective MDLs $(\mu \mathrm{g} / \mathrm{g})$; however, BECs were inconsequential when compared to the lowest selenium concentrations in the samples of each matrix. The BECs and corresponding MDLs were as follows: detritus, 0.17 compared to 0.019 ; sediment, 0.17 compared to 0.009 ; fish, 0.16 compared to 0.022 ; algae, 0.17 compared to 0.012 ; midge, 0.17 compared to 0.012; plankton, 0.47 compared to 0.046. Except for plankton and sediment, these BECs are considered inconsequential relative to the lowest selenium concentrations in the samples of each matrix. BECs for TSS were less than their respective MDLs. TSS sample data were corrected for procedural blanks, whereas total selenium sample data were not blank corrected.

Instrument Detection, Method Detection, and Method Quantitation Limits: The FIHGAAS instrument detection limit for selenium was 0.02 and $0.033 \mu \mathrm{g} / \mathrm{L}$, and $0.04 \mathrm{mg}$ for TSS. MDLs for each matrix for selenium were computed for each analytical block $(n=15)$ using the formula:

$$
3\left(\mathrm{SD}_{\mathrm{b}}^{2}+\mathrm{SD}_{\mathrm{s}}^{2}\right)^{1 / 2}
$$

where

$$
\begin{aligned}
\mathrm{SD}_{\mathrm{b}}= & \text { standard deviation of a blank }(\mathrm{n}=3) ; \text { and } \\
\mathrm{SD}_{\mathrm{s}}= & \text { standard deviation of a low level sample or } \\
& \text { spiked sample }(\mathrm{n}=3) .
\end{aligned}
$$

Calculated MDLs were: water, 0.071 to $0.38 \mu \mathrm{g} / \mathrm{L}$; filtered particulates, $0.004 \mu \mathrm{g} / \mathrm{L}$; sediment, $0.009 \mu \mathrm{g} / \mathrm{g}$ dry weight; algae, $0.012 \mu \mathrm{g} / \mathrm{g}$ dry weight; midge larvae, $0.012 \mu \mathrm{g} / \mathrm{g}$ dry weight; plankton, $0.046 \mu \mathrm{g} / \mathrm{g}$ dry weight; detritus, $0.019 \mu \mathrm{g} / \mathrm{g}$ dry weight; and whole-body fish, $0.022 \mu \mathrm{g} / \mathrm{g}$ dry weight. Method quantitation limits (MQLs) for each matrix were calculated as $3.3 \times$ MDLs. MDLs for TSS were 3.09 and $5.24 \mathrm{mg} / \mathrm{L}$ and MQLs were 10.2 and $17.3 \mathrm{mg} / \mathrm{L}$. Overall, quality-control results for the study were within acceptable limits as specified by USGS.

\section{References Cited}

American Public Health Association, 1998, Standard methods for the examination of water and wastewater (20th ed.), Method 2540: Washington, D.C., American Public Health Association, p. 257-258.

American Society for Testing and Materials, 2003, Standard test method for particle-size analysis of soils, D422-63 (2002), in Annual Book of ASTM Standards, v. 04.08: West Conshohocken, Pa., American Society for Testing and Materials, p. 10-17.

Cutter, G.A., and Bruland, K.W., 1984, The marine biogeochemistry of selenium - a re-evaluation: Limnology and Oceanography, v. 29, no. 6, p. 1,179-1,192.

Universal Instruments Corporation, 1999, Operating manual for Model CM 5014 Coulometer. 
Publishing support provided by:

Rolla Publishing Service Center

For more information concerning this publication, contact: Director, USGS Columbia Environmental Research Center 4200 New Haven Road

Columbia, MO 65201

(573) 875-5399

Or visit the Columbia Environmental Research Center Web site at: http://www.cerc.usgs.gov 
. 